\title{
ANALISIS PROKSIMAT PAKAN BUATAN DENGAN PENAMBAHAN HIDROLISAT TEPUNG BULU AYAM SEBAGAI SUMBER PROTEIN ALTERNATIF BAGI IKAN NILA (Oreochromis sp.)
}

\author{
Dwi Tika Afriani ${ }^{* *}$; Uswatul Hasan'). \\ 1) Fakultas Perikanan, Universitas Dharmawangsa, \\ e-mail: dwitika_afriani@dharamwangsa.ac.id.
}

\begin{abstract}
Feed protein sources for fish so far have fluctuated and still have to be imported from abroad, causing difficulties for farmers. Then you need to look for other sources of protein that are cheaper and easier to obtain. This study aims to determine the effect of increasing the value of protein content in artificial feed added to chicken feather flour hydrolyzate and to find out the best composition of chicken feather meal hydrolyzate added in the artificial feed that provides optimal protein levels for tilapia growth. This research method is an experiment using a completely randomized design (CRD) with three treatments and three replications. Control (-): 100\% conventional artificial feed (PB). Control (+): 100\% Chicken Feather Flour (TBA). Treatment A: 25\% TBA and 75\% PB. Treatment B: $50 \%$ TBA $50 \%$ PB. Treatment C: $75 \%$ TBA and $25 \%$ PB. Proximate tests performed on each sample. The parameters observed were crude protein levels and organoleptic tests. They are analyzed using ANAVA and DMRT tests with a confidence level of $95 \%$, while for organoleptic yield data were analyzed descriptively qualitatively. The results showed that TBA fermentation with B. subtillis could improve the quality of raw materials for fish feed. The highest increase in crude protein in treatment $C(10.40 \pm 0.22)$ with a change in physical properties to brown, pungent odor, and blindness texture.
\end{abstract}

Keywords: Bacillus subtilis, fish feed ingredients, chicken feathers, fermentation.

\begin{abstract}
Abstrak
Pakan sumber protein bagi ikan selama ini berfluktuasi dan masih harus diimpor dari luar negeri menyebabkan kesulitan bagi petani. Maka perlu dicari sumber protein lain yang lebih murah dan mudah didapat. Penelitian ini bertujuan untuk mengetahui pengaruh peningkatan nilai kandungan protein dalam pakan buatan yang ditambahkan dengan hidrolisat tepung bulu ayam dan untuk mengetahui komposisi terbaik penambahan hidrolisat tepung bulu ayam dalam pakan buatan yang memberikan kadar protein yang optimal bagi pertumbuhan ikan nila. Metode penelitian ini adalah eksperimen menggunakan Rancangan Acak Lengkap (RAL) dengan 3 perlakuan dan 3 kali ulangan. Kontrol(-) : 100\% pakan buatan konvensional (PB). Kontrol(+): 100\% Tepung Bulu Ayam (TBA). Perlakuan A: $25 \%$ TBA dan $75 \%$ PB. Perlakuan B: $50 \%$ TBA 50\% PB. Perlakuan C: $75 \%$ TBA dan $25 \%$ PB. Dilakukan uji proksimat pada setiap sampel. Parameter yang diamati adalah kadar protein kasar dan uji organoleptik. Data berupa kadar protein dan serat kasar dianalisis menggunakan ANAVA dan uji DMRT dengan tingkat kepercayaan 95\%, sedangkan untuk data hasil organoleptik dianalisis secara deskriptif kualitatif. Hasil penelitian menunjukkan bahwa Fermentasi TBA dengan B. subtillis dapat meningkatkan kualitas bahan baku pakan ikan. Peninggkatan protein kasar tertinggi pada perlakuan C $(10,40 \pm 0,22)$ dengan perubahan sifat fisik menjadi coklat, berbau menyengat, tekstur burai.
\end{abstract}

Kata Kunci : Bacillus subtilis, bahan pakan ikan, bulu ayam, fermentasi.

\section{PENDAHULUAN}

Meningkatnya permintaan pakan seiring dengan berkembangnya kegiatan budidaya perikanan menjadi sebuah hal yang perlu menjadi perhatian. Sayangnya saat ini harga bahan 
pakan konvensional sumber protein, seperti tepung ikan, dan bungkil kedelai berfluktuasi dan masih harus diimpor untuk memenuhi kebutuhan industri peternakan dan perikanan. Berdasarkan data KKP menyebutkan produksi tepung ikan dalam negeri tahun 2015 sebesar 139.459 ton, sementara kebutuhannya mencapai 211.000 ton. Tahun 2016, KKP menargetkan produksi tepung ikan mencapai 166.241 ton. Impor tepung ikan tahun 2010 mencapai 39.262 ton, 2011 mencapai 75.148 ton, 2012 mencapai 65.793 ton, 2013 mencapai 60.000 ton, dan 2014 mencapai 50.000 ton (Idris, 2015). Keadaan ini menyebabkan masalah produksi bagi petani ikan dan tidak jarang mengalami kerugian.

Untuk mengantisipasi permasalahan tersebut perlu dicari alternatif bahan baku pakan ikan yang memiliki kualitas gizi yang tidak kalah dengan tepung ikan, tetapi harganya terjangkau atau bahkan memanfaatkan limbah. Salah satu alternatif pemanfaatan limbah yang masih memiliki kadar protein tinggi adalah bulu ayam. Setiap harinya limbah bulu ayam dihasilkan dari setiap rumah pemotongan ayam, yaitu sekitar $4-5 \%$ bulu ayam dari bobot hidup ayam pedaging (Sa'adah, dkk., 2013). Namun Pemanfaatan tepung bulu ayam dalam campuran pakan, perlu diperhatikan beberapa hal seperti stuktur proteinnya. Protein bulu ayam merupakan jenis protein yang sulit dicerna, karena tergolong jenis protein keratin (Joshi, dkk., 2007).

Rendahnya daya cerna protein tersebut menjadi satu kendala untuk menjadikan bulu ayam sebagai sumber protein pakan ikan. Oleh karena itu, untuk meningkatkan kualitas tepung bulu ayam sebagai bahan baku pakan ikan, terlebih dahulu tepung bulu ayam harus didegradasi, salah satunta dengan cara difermentasi.

Mikroorganisme pendegradasi keratin di antaranya adalah jenis bakteri Bacillus sp. (Tiwary \& Gupta, 2012). Bakteri B. licheniformis pernah digunakan dalam fermentasi untuk memecah keratin bulu ayam pada konsentrasi inokulum sebesar 6,5 x $109 \mathrm{koloni} / \mathrm{ml}$ dengan jumlah inokulum sebesar $10 \mathrm{ml}$. Hasilnya menunjukkan bahwa setelah fermentasi, kadar protein kasar bulu ayam meningkat dari $95,17 \%$ menjadi $97,12 \%$ atau meningkat sebesar 2,95\% (Desi, 2002). Penelitian lain dilakukan Tiwary \& Gupta (2012) yang menggunakan B. subtilis untuk mendegradasi bulu ayam. Hasil penelitian menunjukkan terjadinya kenaikan protein dari $57,8 \%$ menjadi $73,4 \%$. Dengan menggunakan jenis isolat yang sama, pada penelitian pendahuluan yang telah dilakukan membuktikan bahwa fermentasi dengan bakteri B. subtilis dengan konsentrasi $5 \mathrm{ml}$ mampu meningkatkan kadar protein dari $73.56 \%$ menjadi $84.09 \%$, dengan perubahan tekstur lebih lembut, lebih coklat dan bau lebih menyengat.

Penelitian ini bertujuan untuk mengetahui pengaruh peningkatan nilai kandungan protein dalam pakan buatan yang ditambahkan dengan hidrolisat tepung bulu ayam dan untuk mengetahui komposisi terbaik penambahan hidrolisat tepung bulu ayam dalam pakan buatan yang memberikan kadar protein yang optimal bagi pertumbuhan ikan nila.

\section{METODE}

Metode penelitian ini adalah eksperimen menggunakan Rancangan Acak Lengkap (RAL) dengan 5 perlakuan dan 3 kali ulangan. Pembuatan tepung bulu ayam dilakukan dengan cara bulu ayam dikumpulkan dan diambil dari RPA. Bulu ayam yang terkumpul dicuci hingga bersih dengan air mengalir. Kemudian dikeringkan dan digiling menggunakan mesin giling (Tarmizi, 2001).

Purifikasi bakteri dilakukan pada media NA. Selanjutnya, dibuat inokulum bakteri tersebut dan ditumbuhkan pada media NA yang dibuat miring pada tabung reaksi dan diinkubasi pada suhu kamar selama 48 jam. Sebanyak $10 \mathrm{ml}$ NB dimasukkan ke dalam tabung biakan bakteri sehingga diperoleh suspensi sel bakteri yang disebut dengan inokulum (Desi, 2002).

Perbanyakan bakteri dilakukan dengan menginokulasi biakan pada media NA dan diinkubasi selama 48 jam. Isolat dipindahkan ke dalam $10 \mathrm{ml}$ media NB dan diinkubasi pada 
$\mathrm{pH} 8,0$ dan suhu $45^{\circ} \mathrm{C}$ selama 5 hari. Kultur yang dihasilkan dipindahkan seluruhnya ke dalam $90 \mathrm{ml}$ media NB dan diinkubasi selama 48 jam. Seluruh kultur dipindahkan ke dalam $900 \mathrm{ml}$ media NB dan diinkubasi kembali selama 48 jam. Hasil akhir dari proses ini diperoleh kultur bakteri yang digunakan untuk proses fermentasi sebanyak $1000 \mathrm{ml}$ (Desi, 2002). Konsentrasi dihitung dengan cara pengenceran. Sebanyak $1 \mathrm{ml}$ kultur diencerkan dalam beberapa kali tingkat pengenceran. Pengenceran dilakukan dengan menggunakan larutan $\mathrm{NaCl} \mathrm{0,1} \mathrm{M}$ steril. Pada tiga pengenceran terakhir yaitu 10-5, 10-6, dan 10-7 masing-masing diambil $1 \mathrm{ml}$ dan dituangkan pada cawan petri steril. Medium NA ditambahkan ke dalam cawan petri dan dibiarkan selama $2 \times 24$ jam. Penghitungan jumlah koloni dilakukan dengan menggunakan metode Total Plate Count (TPC) (Desi, 2002).

Proses fermentasi dilakukan dengan terlebih dahulu melakukan sterilisasi tepung bulu ayam pada $121{ }^{\circ} \mathrm{C}, 1 \mathrm{~kg} / \mathrm{cm} 2$ selama 15 menit dengan tujuan untuk menghilangkan mikroorganisme ikatan atau mencegah terjadinya kontaminan oleh mikroorganisme lain. Sebanyak 2 g tepung bulu ayam dicampurkan dengan masing-masing inokulum cair mikroba sebanyak 5ml, ke dalam erlenmeyer pada $\mathrm{pH} 8,5$ dan diinkubasi dalam inkubator pada suhu $55^{\circ} \mathrm{C}$ selama $72 \mathrm{jam}$. Hasilvdari proses fermentasi diperoleh tepung bulu ayam yang disebut dengan hidrolisat bulu ayam (HBA) (Afriani, 2017).

Hidrolisat bulu ayam yang telah diperoleh dari hasil fermentasi kemudian dikeringkan dan dipenambahankan ke dalam pakan buatan dengan komposisi sesuai dengan perlakuan , sebagai berikut: Kontrol (-) : 100\% pakan buatan konvensional. Kontrol (+): 100\% Tepung Bulu Ayam. Perlakuan A: Penambahan 25\% Tepung Bulu Ayam dan 75\% pakan buatan konvensional. Perlakuan B: Penambahan 50\% Tepung Bulu Ayam dan 50\% pakan buatan konvensional. Perlakuan C: Penambahan 75\% Tepung Bulu Ayam dan 25\% pakan buatan konvensional. Setiap pakan uji dilakukan analisis proksimat di laboratorium biokimia. Parameter yang diamati adalah uji proksimat terhadap kadar protein kasar dan uji organoleptik pada pakan uji, meliputi warna, tekstur dan bau.

\section{HASIL DAN PEMBAHASAN \\ Protein Kasar}

Perlakuan $\mathrm{C}$ dengan $75 \%$ tepung bulu ayam fermentasi dan $25 \%$ pakan buatan menunjukkan nilai kadar protein tertinggi dibandingkan dengan kombinasi perlakuan A dan B. hal ini dikarenakan perbandingan tepung bulu ayam yang digunakan juga lebih banyak dibanding perlakuan lain. Menurut puastuti, bulu ayam mengandung protein kasar yang sangat tinggi, yakni sebesar $74,4-91,8 \%$ dari bahan kering. Protein kasar merupakan protein yang sulit dicerna dan terdiri dari semua ikatan yang mengandung nitrogen, baik protein sesungguhnya maupun zat -zat yang mengandung protein. Pada pakan buatan yang digunakan selama penelitian, semakin banyak tepung bulu ayam yang digunakan maka hasil uji kandungan protein pada pakan buatan akan semakin tinggi (Puastuti,2004).

Peningkatan kadar protein kasar pada tepung bulu ayam terjadi karena proses fermentasi. Hal ini karena adanya aktivitas keratinase yang dihasilkan oleh bakteri B. subtilis. Brandelli menyatakan bahwa B. subtilis mampu memproduksi enzim keratinase dalam jumlah tinggi (Brandelli,2008). Keratinase merupakan enzim protease spesifik yang memiliki kemampuan memecah substrat keratin. Enzim keratinase dihasilkan oleh bakteri jenis Bacillus tergolong enzim ekstraseluler. Enzim tersebut mampu menghidro-lisis berbagai protein larut dan protein tidak larut seperti protein keratin (Sinoy,2011).

\section{Serat Kasar}

Kadar serat kasar terendah ditunjukkan oleh perlakuan $\mathrm{C}$ dengan nilai $0,90 \%$. Penurunan serat kasar disebabkan oleh menurunnya serat dalam protein keratin akibat adanya proses fermentasi. Proses fermentasi oleh bakteri penghasil enzim keratinase dan reduktase 
mampu menghidrolisis ikatan peptida dan disulfida pada protein keratin. Banyaknya serat kasar yang dikandung suatu bahan pakan menyebabkan sel dinding yang kuat dan akibatnya daya cerna pakan menjadi rendah (Wulandari,2013). Puastuti (2004) menyatakan bahwa kecernaan bahan kering tepung bulu ayam menunjukkan nilai yang lebih baik setelah dilakukan pemrosesan. Hal ini juga didukung oleh pernyataan Tillman yang menyatakan bahwa kecernaan serat kasar tergantung pada kandungan serat kasar dalam ransum dan jumlah serat kasar yang dikonsumsi (Tilman,2005).

Tabel 1. Kadar Serat Kasar dan Protein pada Sampel

\begin{tabular}{l|cc}
\hline & Protein (\%) & Serat kasar (\%) \\
\hline Kontrol - (0\%) & $8,56 \pm 0,23^{\mathrm{a}}$ & $5,30 \pm 0,13^{\mathrm{d}}$ \\
kontrol + (100\%) & $13,00 \pm 0,15^{\mathrm{c}}$ & $0,52 \pm 0,17^{\mathrm{a}}$ \\
Perlakuan A (25\%) & $8,41 \pm 0,19^{\mathrm{a}}$ & $1,05 \pm 0,15^{\mathrm{b}}$ \\
Perlakuan B (50\%) & $8,92 \pm 0,10^{\mathrm{a}}$ & $2,52 \pm 0,12^{\mathrm{c}}$ \\
Perlakuan C (75\%) & $10,40 \pm 0,22^{\mathrm{b}}$ & $0,90 \pm 0,21^{\mathrm{ab}}$ \\
\hline
\end{tabular}

Keterangan : Huruf superskrip yang berbeda menunjukkan hasil yang berbeda nyata pada uji DMRT dengan taraf uji $5 \%$.

Tabel 2. Uji Organoleptik

\begin{tabular}{cccc}
\hline Perlakuan & Parameter & Rerata & Keterangan \\
\hline \multirow{2}{*}{ Kontrol - (0\%) } & warna & 3,25 & cukup coklat \\
& bau & 1,31 & sangat kurang menyengat \\
& tekstur & 4,65 & Sangat burai \\
Kontrol + (100\%) & warna & 4,33 & coklat \\
& bau & 4,13 & menyengat \\
& tekstur & 4,89 & sangat burai \\
Perlakuan A (25\%) & warna & 3,12 & cukup coklat \\
& bau & 2,32 & kurang menyengat \\
& tekstur & 4,75 & sangat burai \\
Perlakuan B (50\%) & warna & 4,36 & coklat \\
& bau & 2,38 & kurang menyengat \\
& tekstur & 4,64 & sangat burai \\
Perlakuan C (75\%) & warna & 4,43 & coklat \\
& bau & 4,35 & menyengat \\
& tekstur & 4,57 & sangat burai \\
\hline
\end{tabular}

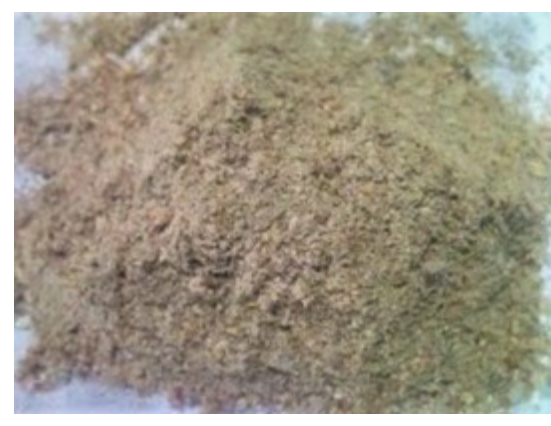

a. TBA Non Fermentasi

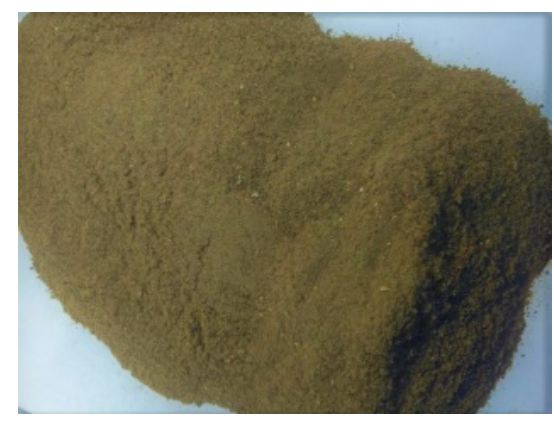

b. TBA Fermentasi 


\section{KESIMPULAN}

Hasil penelitian menunjukkan bahwa Fermentasi tepung bulu ayam menggunakan B. subtillis dapat meningkatkan kualitas bahan baku pakan ikan. Peninggkatan protein kasar tertinggi pada perlakuan $\mathrm{C}(10,40 \pm 0,22)$ dengan perubahan sifat fisik menjadi berwarna coklat, berbau menyengat, dan bertekstur burai.

\section{DAFTAR PUSTAKA}

Afriani.D.T., 2017, Efektivitas Penggunaan dan Dosis Mikroba Terhadap Peningkatan Kualitas Tepung Bulu Ayam Sebagai Pakan Alternatif, Jurnal Poliprofesi, XII (1):26-32.

Brandelli, A. 2008. Bacterial keratinases: useful enzymes for bioprocessing agroindustrial wastes and beyond. Food Bioprocess Technol. 1, 105-116.

Desi, M. 2002. Aktivitas keratinase Bacillus licheniformis dalam memecah keratin bulu ayam. Skripsi. Fakultas Matematika dan Ilmu Pengetahuan Alam. Bogor : Institut Pertanian Bogor.

Idris, M. 2015. RI Masih Impor Tepung Ikan dari Peru dan Cile. http://finance.detik.com. Diakses tanggal 3 Mei 2018.

Joshi. S. G., M. M. Tejashwini, N. Revati, R. Sridevi, \& D. Roma. 2007. Isolation, Identification and Characterization of Feather Degrading Bacterium. India : Department of Biotechnology.

Puastuti, W., D. Yulistiani dan I.W. Mathius. 2004. Bulu ayam yang diproses secara kimia sebagai sumber protein bypass rumen. JITV. 9(2): 73-80.

Sa'adah, N., R. Hastuti, \& N. B. A. Prasetya. 2013. Pengaruh asam formiat pada bulu ayam sebagai adsorben terhadap penurunan kadar larutan zat warna tekstil remazon golden yellow RNL. Jurnal Kimia Universitas Diponegoro. I(1): 202-209

Sinoy, S., Bhausaheb, T.C.P., dan Rajendra, P.P., 2011. Isolation and identification of feather degradable microorganism. VSRD-TNTJ, 2(3):128-136.

Tillman, A. D., H. Hartadi, S. Reksohadiprodjo, S. Prawirokusumo dan S.Lebdosoekojo. 2005. Ilmu Makanan Ternak Dasar. Gadjah Mada University Press, Yogyakarta.

Tarmizi, A. 2001. Evaluasi nilai nutrisi tepung bulu yang difermentasi dengan menggunakan Bacillus licheniformis pada ayam broiler. Skripsi. Jurusan Ilmu Nutrisi dan Makanan Ternak Fakultas Peternakan. Bogor: Institut Pertanian Bogor.

Tiwary, E. \& R. Gupta. 2012. Rapid conversion of chicken feather to feather meal using dimeric keratinase from Bacillus licheniformis ER-15. J. Bioproces Biotechniq. 2:4.

Wulandari, Adi, W., dan Rahayu, S., 2013. Kecernaan Lemak dan Energi Konsentrat Monogastrik Berbasis Hidrolist Tepung Bulu Ayam secara In Vitro. Jurnal Ilmiah Peternakan, 1(2):430436. 